\title{
Effects of treatment with leptin-like peptides on factors related to body fat control in Wistar rats fed a high-fat diet*
}

\author{
Elpidia Poveda, MSc ${ }^{1}$, Francisco Ruiz, Esp², María Carlina Castillo, Esp ${ }^{2}$
}

\section{SUMMARY}

Introduction: The results of administering recombinant leptin, as well as the 116-130 peptide of mouse leptin in ob/ob mice have shown the probability of discovering more efficient leptin-based therapeutic methods to treat obesity.

Objective: To demonstrate in Wistar rats fed with high-fat diet if the administration of synthetic peptides corresponding to the 116-130 peptide of mouse leptin (SR 116), its human homologue peptide (SH 95: sequence 95-109 from the 1AX8 protein) and five modified peptides (P80 to P84) similar to these two peptides, produces effects related to regulation of body fat.

Materials and methods: Nine-week old Wistar rats were fed a high-fat diet for fifteen weeks. On the fifteenth week, and for five consecutive days, they were treated with the peptides to be evaluated. During the days of treatment, body weight and food intake were evaluated. After the last peptide administration, lipid profile, glycerol in the cellular medium, and DNA fragmentation in adipocytes were analyzed.

Results: The results revealed that: the SR1 16 peptide affects the regulation of adiposity in rats fed a high-fat diet. The SH 95 is the human peptide with biological activity similar to SR 116 to lower weight, lessen food intake, and increase free glycerol in the cellular medium. The P80 and P81 peptides had a similar effect on SR 116 and SH 95 regarding body weight and food intake. The SR 116, SH 95 and three of the modified peptides (P80, P81, and P82) caused DNA fragmentation.

Conclusion: The results suggest that peptides analogous to leptin are potentially viable to achieve effects of adiposity reduction in Wistar rats with obesity associated to high-fat diet; more research is rendered to explain the differences among peptides and the biological action mechanisms.

Keywords: Dietary fats; Adiposity; Leptin analogs; Therapeutic; Rat Wistar rat.

Colomb Med. 2011; 42: 61-71

Efectos del tratamiento con péptidos similares a leptina sobre factores asociados con el control de grasa corporal en ratas Wistar alimentadas con dieta alta en grasa

\section{RESUMEN}

Introducción: Los resultados de administrar leptina recombinante así como del péptido 116-130 de leptina de ratón en ratones ob/ob han demostrado la probabilidad de descubrir métodos terapéuticos más eficientes basados en leptina para tratar la obesidad.

Objetivo: Comprobar, en ratas Wistar alimentadas con dieta alta en grasa, si la administración de los péptidos sintéticos correspondientes al péptido 116-130 de leptina de ratón (SR 116), péptido humano similar al de ratón (SH 95), correspondiente a la secuencia 95-109 de la proteína 1 AX8 y cinco péptidos modificados (P80 a P84), similares a estos dos péptidos produce efectos relacionados con la regulación de la grasa corporal.

Materiales y métodos: Ratas de 9 semanas de edad recibieron, durante 15 semanas, una dieta alta en grasa. En la semana

* The project was funded by the Colombian National Health Institute and Pontifica Universidad Javeriana, as well as COLCIENCIAS as co-funding entity (Project code 2104-04-12689).

1. Nutrition Group, Sub-direction of Research, Instituto Nacional de Salud, Bogotá, DC, Colombia. e-mail: epoveda1@yahoo.com

2. Specialized Professional, Sub-direction of Production, Bioterio, Instituto Nacional de Salud, Bogotá, DC, Colombia. e-mail: fruiz@ins.gov.co mcastillo@ins.gov.co Received for publication August 9, 2010 Accepted for publication November 9, 2010 
15, por 5 días consecutivos, se trataron con los péptidos a evaluar. Durante los días de tratamiento se evaluó el peso corporal y el consumo de alimento. Después de la última administración de los péptidos se analizó perfil lipidio, glicerol en el medio celular y fragmentación del ADN en adipocitos.

Resultados: Los resultados muestran que el péptido SR116 ejerce efectos sobre el control de la adiposidad en ratas alimentadas con dieta alta en grasa. El SH 95 es el péptido humano con actividad biológica similar al SR 116 para reducir peso, consumo de alimento y mayor liberación de glicerol en el medio celular. Los péptidos P80 y P81 produjeron un efecto similar al SR 116 y al SH 95 en cuanto a peso corporal y consumo de alimento. El SR 116, SH 95 y tres de los péptidos modificados (P80, P81 y P82) ocasionaron fragmentación del ADN.

Conclusión: Los resultados indican que péptidos análogos a la leptina son potencialmente viables para lograr efectos de reducción de la adiposidad en ratas Wistar con obesidad asociada con dietas altas en grasa. Se requieren otras investigaciones para explicar las diferencias entre péptidos y los mecanismos de acción biológica.

Palabras clave: Grasas en la dieta; Adiposidad; Análogos de leptina; Terapéutica; Ratas Wistar.

\section{Colomb Med. 2011; 42: 61-71}

Leptin is a protein mainly synthesized in the adipocytes, conformed in the mature state by 146 amino acids. Its principal function is related to regulation of fat deposits through endocrine, autocrine, and paracrine actions that modulate appetite and regulate lipid metabolism by increasing lipolysis and oxidation of fatty acids, and inhibiting triglyceride synthesis within the adipocyte ${ }^{1-4}$.

It has been noted that in mice with mutations in the leptin gene (ob/ob mice) obesity and hyperglycemia are associated to the lack of endogenous leptin. In obese humans and obese rats, on the contrary, there are high concentrations of plasma leptin, concomitant with hyperphagia, hyperglycemia, and other metabolic sequelae characteristic of obesity, suggesting a condition resistant to leptin ${ }^{5-9}$.

The function of leptin in body fat regulation and in the pathological alterations observed when the protein is absent or when it is increased excessively led to considering it a potential alternative for the treatment of obesity and its co-morbidities. Initially, we tested the administration of recombinant leptin, finding some effects in decreasing body weight, diminishing insulinemia, apoptosis in adipocytes, and reduction of total cholesterol plasma concentrations, phospholipids, free fatty acids, triglycerides, LDL cholesterol (LDLc), and VLDL cholesterol (VLDL-c), as well as increased concentrations of HDL cholesterol (HDLc) ${ }^{10-14}$.

It has been observed that in animal models, the administration of recombinant leptin results more favorable in controlling adiposity when administered in intracerebroventricular (ICV) ${ }^{13}$ manner, which indicates that it would not be a viable therapeutic method for use in human subjects. Studies where recombinant leptin has been administered in humans reveal inconclusive results ${ }^{10}$. For this reason the possibility was considered of using synthetic peptides that would conserve the primary structure of the active segment. Initially, Grasso et al. ${ }^{5}$, and Rozhavskaya et al. ${ }^{6}$ tested the synthetic peptide corresponding to the mouse 116-130 leptin segment in ob/ob mice, managing to reduce body weight, appetite, and glucose. They then tested with the peptide corresponding to the mouse 116-122 leptin sequence, but substituting the amino acid from the 119 position for its D-isomer D ([D-Leu-4]-OB3, finding a greater reduction of body weight, appetite, and glucose $\mathrm{e}^{5-7}$.

The experiments by Grasso et al. ${ }^{5}$ reveal that peptides of between seven and 15 amino acids of the active sequence are able to reproduce the activity of the native protein and, additionally, indicate that the activity depends upon the conformation of the peptide ${ }^{5-7}$. The use of small peptides active in humans would reduce the immunological risks of administering complete proteins. From these considerations, the objectives of this research were:

1. To prove if the synthetic peptide corresponding to the mouse 116-130 leptin sequence(SR116) obtained by Grasso could produce similar effects in an animal model of Wistar rats with obesity associated to a high-fat dietary intake.

2. To prove if the human peptide (SH 95), previously postulated ${ }^{15,16}$ by our research group as homologous to the mouse 116-130 leptin (sequence 95-109 of the human leptin identified in the Protein Data Bank (PDB) as $1 \mathrm{AX} 8)^{15,16}$ has the potential to carry out the same biological functions of murine regarding weight control and control of food intake in the rat model.

3. To determine other effects of SR 116 and SH 95 on 
the lipid profile, liberation of glycerol in the cellular medium of adipose cells and fragmentation of adipocyte DNA.

4. To assess if five peptides constructed from computational studies of sequence similarity and minimum potential energy related with SR 116 and SH 95 ${ }^{15,16}$ produce these same biological effects.

\section{METHODS}

Peptides. The conditions to carry out peptide synthesis and the sequences were previously published ${ }^{16}$ and correspond to the following peptides:

1. SR 116: SCSLPQTSGLQKPES

2. SH 95: SCHLPEASGLETLDS

3. P80: SCHLPEASDLETLDS

4. P81: GCHLPEASGLETLDS

5. P82: DCHLPEASGLETLDS

6. P83: MCHLPEASGLETLDS

7. P84: CCHLPEASGLETLDS

Animals and experimental design. The description of the animal model used in this study was detailed in a prior publication ${ }^{16}$. This is hereinafter summarized in general manner:

An animal model was used with 180 female Wistar rats, nine weeks of age, supplied by the Colombian Instituto Nacional de Salud(INS for its name in Spanish). Upon starting the experiment, the animals were divided into a control group fed a normal diet (is a low-fat diet with $10 \% \mathrm{kcal}$ on fat but we denominated as normal diet or normal control), a control group fed a high-fat diet, and an experimental group fed a high-fat diet. All the groups received the corresponding diet for a 15week period.

The selection of a 15 -week period is substantiated by prior studies that have shown that after 12 weeks of feeding with these types of high-fat diets, the rats manage to get significantly heavier than those fed normal diets ${ }^{17}$. Likewise, it was decided on a period of time not over 15 weeks because the evidence reveals that as the animals become older there is greater possibility of a state of leptin resistance associated to aging. Our particular interest was to achieve increased leptin concentrations related to diet in young adult animals ${ }^{16,17}$.

On the $15^{\text {th }}$ week, the experimental group was divided into seven groups according to the peptide that would be administered and each of the seven groups was also divided into four subgroups according to the dosage administered ${ }^{16}$ (dosage of $2.5 \mathrm{mg} / \mathrm{kg} ; 5 \mathrm{mg} / \mathrm{kg}, 10 \mathrm{mg}$ / $\mathrm{kg}$, and $20 \mathrm{mg} / \mathrm{kg}$ ).

The peptides were administered intraperitoneally (IP) for five consecutive days, bearing in mind some studies where recombinant leptin was administered for the same period ${ }^{18}$. The volume established was always injected in the lower right abdominal region of the animals. The control groups received $1 \mathrm{mg} / \mathrm{kg}$ of weight/ day of PBS solution via IP during these same five days.

In vivo determinations. During peptide administration, changes in body weight and food intake were evaluated. Twenty-four hours after the last peptide administration blood was extracted via intra-cardiac manner to determine blood concentrations of total cholesterol (TChol), triglycerides (TG), LDLc and HDLc. Immediately after collecting the blood, we proceeded to dissect and extract adipose tissue from the region where the peptides were administered to then study the possible effects related to glycerol liberation in the cellular medium of adipose cells and DNA fragmentation in adipocytes ${ }^{17}$.

Serum lipid concentration. Serum lipid concentrations were determined with Serapak-Bayer reagents. TChol and TGs were quantified via enzymatic methods -colorimetry and HDLc were measured from the supernatant after LDLc precipitation with phosphotungstic acid and magnesium ions. LDLc concentrations were calculated through the difference between the TChol concentration and the total cholesterol present in the supernatant, which corresponds to VLDL cholesterol and to HDLc.

Evaluation of glycerol liberated in the cellular medium of adipocytes. We examined concentrations of glycerol liberated in the cellular medium after subjecting the intraperitoneal target adipose tissue from the zone where peptide was administered toa process of digestion, filtration, and separation. The procedure to determine glycerol is an adaptation of the methodologies described in different publications ${ }^{2,4,19}$ :

One gram $(1 \mathrm{~g})$ of adipose tissue was taken from the region where the peptides were administered. Then, the tissue was subjected to digestion with collagenase through agitation for 90 minutes at $37^{\circ} \mathrm{C}$; the process was carried out in $50 \mathrm{ml}$ polypropylene tubes. After the digestion period, the resulting cell suspension was 
filtered through a nylon $100 \mu \mathrm{m}$ mesh (steriflip filter unit Millipore type NY1H), Krebs-Ringer bicarbonate (KRB) was added and centrifuged for one minute at 400 rpm to eliminate the stromal vascular fraction. Again, a fraction of the supernatant was taken, and KRB was added again and it was centrifuged another time; this procedure was repeated one more time, for a total of three washing sessions and replacement of the medium. Then, part of the supernatant was taken and incubated at $37^{\circ} \mathrm{C}$ for 90 minutes in $50 \mathrm{ml}$ polypropylene tubes. Thereafter, $1000 \mu \mathrm{l}$ of the intermediate fraction was centrifuged at $10000 \mathrm{rpm}$ for one minute. Then, the intermediate fraction of the adipocyte-free supernatant was transferred to reaction tubes and stored at $-70^{\circ} \mathrm{C}$, until the moment of glycerol quantification.

The digestion solution contained a Krebs-Ringer bicarbonate buffer solution (product $\mathrm{N}^{\circ} \mathrm{K} 4002$ from Sigma with sodium bicarbonate); bovine serum albumin V fraction, $3.5 \mathrm{~g} / 100 \mathrm{ml}$ (Sigma A3294 product); glucose $(1 \mathrm{mM})$, and collagenase type II (Sigma product $\mathrm{N}^{\circ}$ C6885). Per gram of fat tissue the proportion of digestion solution was $5 \mathrm{ml}$ and $6.7 \mathrm{mg}$ of collagenase. The solution presented $\mathrm{pH}$ of 7.4. To determine the concentration of free glycerol in the medium, $10 \mu 1$ were taken from the supernatant. An enzymatic-colorimetric method was used with SERAPK BAYER reagents of triglyceride quantification (Sera-Pak Plus triglyceride stable liquid $\left.\mathrm{N}^{\circ} \mathrm{B} 01-4512-01\right)$. The Merck Mega autoanalyzer technique was used as quantification equipment.

Evaluation of DNA fragmentation in adipose tissue. We studied the possible fragmentation of deoxyribonucleic acid (DNA) in target adipose tissue from the region where the peptide or the phosphatebuffer solution (PBS) were administered. The procedure was divided into two phases: the first was isolation of DNA from the target adipose tissue and the second was electrophoresis in polyacrylamide gel to observe the DNA bands; the method was the following:

DNA isolation from intraperitoneal target adipose tissue. The protocol to isolate DNA from adipose tissue was adapted from the methodology described by Gullicksen $\mathrm{PS}^{20}$ and the protocol for DNA detection from the genomic DNA purification kit from Wizard (isolation of genomic DNA from animal tissue p.10, Promega A1120).

One milliliter of the buffer solution was added to
$250 \mathrm{mg}$ of adipose tissue for lysis (10 mM Tris-HCL, 10 $\mathrm{mM}$ of EDTA, $0.5 \%$ of Triton X-100, $\mathrm{pH} 8.0$ ), then macerated and homogenized. When the tissue was macerated, it was transferred to a reaction tube, incubated in ice for 20 minutes, and then centrifuged for 5 minutes at $13,000 \mathrm{rpm}$ and at $4^{\circ} \mathrm{C}$. The pellet (residue) remaining at the bottom of the tube corresponds to insoluble DNA and the supernatant to the soluble DNA. The fat cake observed on the supernatant was discarded and soluble DNA was separated from insoluble DNA.

Both insoluble DNA and soluble DNA received 600 $\mu 1$ of lysis solution for nucleic acids from the Promega Wizard kit, and were incubated at $56^{\circ} \mathrm{C}$ with agitation for one hour. Each of the tubes received $3 \mu \mathrm{l}$ of the RNAase solution from Wizard and these were mixed by inversion. They were left for 15 minutes at $37^{\circ} \mathrm{C}$ and then cooled to room temperature for five minutes or in ice for 2 minutes.

Some $200 \mu \mathrm{l}$ of the protein precipitating solution were added and mixed in vigorous vortex for 15 seconds. When the amount of soluble or insoluble DNA was greater than $1.5 \mathrm{ml}$, half was transferred to another reaction tube and $100 \mu 1$ of the precipitating solution was added to each tube. The tubes were left in ice for five minutes and were centrifuged at $13,000 \mathrm{rpm}$ for five minutes.

The supernatant of insoluble DNA and soluble DNA was again transferred to other reaction tubes; $600 \mu \mathrm{l}$ of absolute ethanol were added, the solution was mixed by inversion to observe the DNA strands. It was centrifuged for 1-2 minutes between 13,000 and 16,000 rpm at room temperature and the supernatant was decanted.

The tubes were left to dry for 15 minutes. Then, 100 $\mu 1$ of tris-HCL and EDTA (TE) were added to the insoluble DNA, and if there two tubes $50 \mu 1$ were added to each tube. A total of $30 \mu \mathrm{l}$ of TE were added to the soluble DNA or $15 \mu \mathrm{l}$ per tube if there were two tubes.

DNA Electrophoresis of target adipose tissue from the peritoneal region. Electrophoresis was performed on the soluble and insoluble DNA fractions in polyacrylamide gel at $6 \%$. The gel was prepared at $6 \%$ (distilled water: $28 \mathrm{ml}$, tris-borate (TBE) 10X: $4 \mathrm{ml}$, $30 \%$ acrylamide stock: $8 \mathrm{ml}$, ammonium persulfate at 10\%: $240 \mu \mathrm{l}$ and N, N, N',N'-tetramethylethelenediamine (TEMED): $24 \mu \mathrm{l}$ and left to polymerize for one hour. Plate size was $17 \times 14 \mathrm{~cm}$ with a capacity for 16 samples. 
As marker, we used 100 bp DNA Ladder (Promega catalogue $\left.\mathrm{N}^{\circ} \mathrm{G} 2101\right), 2 \mu 1$ per gel. We seeded $30 \mu \mathrm{l}$ of the simple with $5 \mu \mathrm{l}$ of load buffer and electrophoresis was run at a voltage of $1 \mathrm{P} 80 \mathrm{~V}$ for two hours. TBE $1 \mathrm{X}$ was used as buffer; ethidium bromide was used as colorant for 15 minutes and in cases requiring better band resolution an additional SYBR Green I nucleic Acid Gel Stain (from molecular probes) was used as colorant for 45 minutes. For $400 \mathrm{ml}$ of distilled water we added $20 \mu 1$ of ethidium bromide and for $400 \mathrm{ml}$ of TBE 10X $40 \mu 1$ of SYBR Green.

DNA was visualized in a UV transilluminator and photographs of the gel were taken with a black and white Polaroid 667 film.

Statistical analysis. Data bases to manage data were created in Excel and the statistical analysis was carried out with the SPSS program, version 15 for Windows. The variables studied were described by groups, using the mean and standard deviation. To test differences among groups in the study variables analysis of variance (ANOVA) was applied and in cases in which this test determined statistically significant differences posthoc comparisons were made through the Duncan test. Analyses were worked at a confidence level of $95 \%$ $(p<0.05)$. DNA fragmentation results only indicate the groups in which there was fragmentation.

Assessment of peptide effect upon body weight was complemented through the calculation of the slope for each weight curve corresponding to the period of peptide administration.

Ethical considerations. Tests were conducted according to scientific, technical, and administrative guidelines for health research (Resolution $\mathrm{N}^{\circ} 8430$ of 1993), Legislation 84 of 1989 «Through which is adopted the National Statute for Animal Protection», and the ethical principles of animal experimentation from the International Council for Laboratory Animal Science. The study was approved by the Ethics Committee at the INS.

\section{RESULTS}

Change of weight during the administration of the peptides. In order to establish if the peptides administered during the five days of treatment would produce some variation in animal weight, we compared the weight prior to administering the peptides (or the weight before administering PBS for the control groups) with the weight at the end of the test (comparison before and after administration). The comparison revealed that there was a weight decrease in all the experimental groups, with the exception of P84 (Table 1). Weight loss ranged between $-0.2 \%$ and $-2.4 \%$ (-0.6 $\mathrm{g}$ and -7.1 g). The normal control group increased and the fat control group lost weight slightly without the differences being statistically significant (Table 1).

The prior analysis was based on the weight differences at the beginning and end of the peptide administration period. However, it is possible to follow the effect along the five days by determining the slope of the curve of the weight decrease for each group. Table 2 shows the tendency for body weight reduction in the experimental groups, especially in the SR116, SH95, and P80 to P81 peptides.

To determine if the effect of the peptides on weight change was statistically different, we used the ANOVA and Duncan tests. We tested to see if there were differences among peptide groups (ANOVA: $\mathrm{p}<0.00009$ ): groups SR116, SH95, P80, and P81 presented weight reduction similar among them and greater than the change observed in groups P82, P83, and P84; nevertheless, the differences were statistically significant among groups P78 to P81 and the normal control and P84 groups. The weight change in group P84 was not differentiated from the change observed in the two controls or in groups 82 and 83 (Table 2).

When comparing the slopes according to the peptides, differences were found among the groups (ANOVA $\mathrm{p}<0.00009$ ), identifying two groups in relationship to the effect observed: the first, conformed by groups SR 116, SH95, P80, and P81, which show the most negative slopes and without differences among them, while the group conformed by P82, P83, P84, and fat control show insignificant negative slopes. Weight reduction by SR116 and SH95 was statistically significant with respect to the weight change of the controls and from the P82 to P84 peptides (Table 2).

The subgroups from each of the experimental groups receiving peptide dosages of $2.5,5,10$, and $20 \mathrm{mg} / \mathrm{kg}$ of weight did not show statistically significant differences among them, nor was any type of dosage effect response noted (ANOVA $\mathrm{p}>0.05$ ).

Food intake during peptide administration. To establish the effect of peptides on food intake, we 


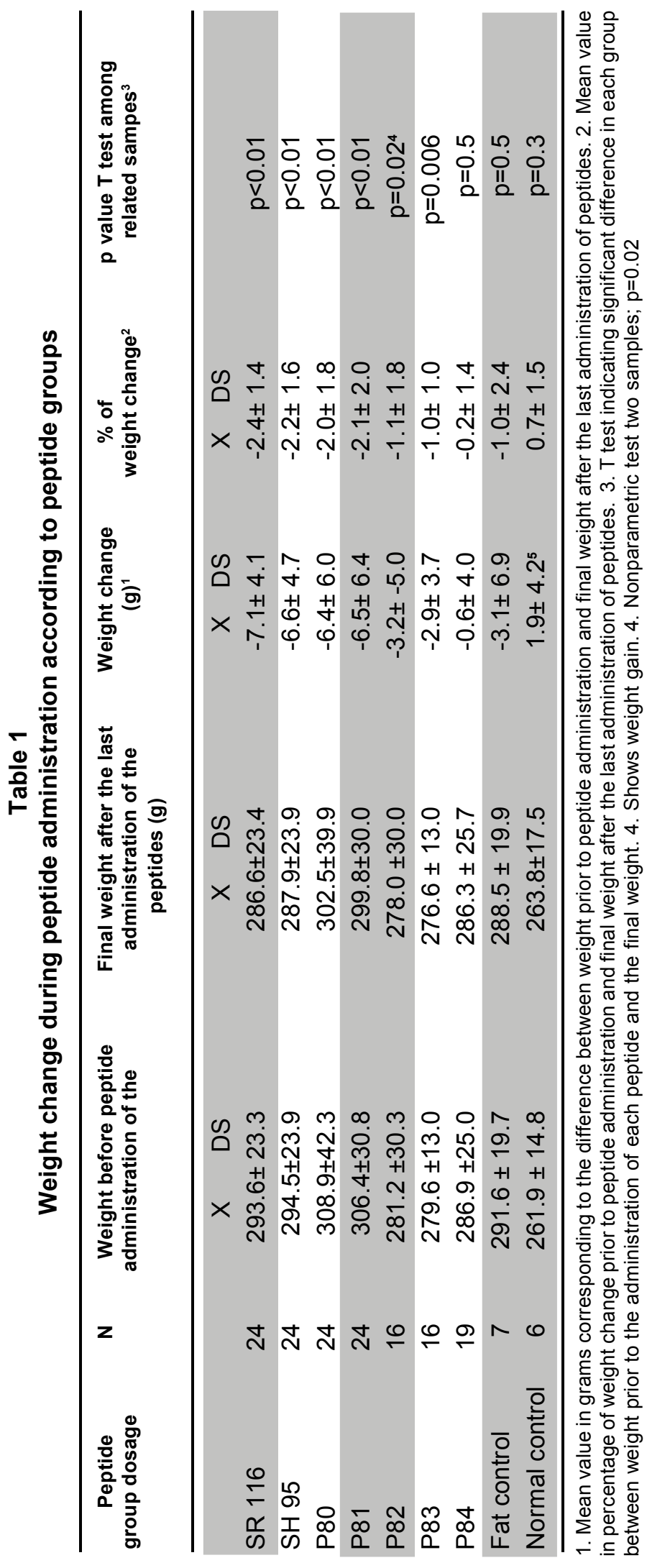

compared the food consumed during the five days prior to peptide administration with consumption during the five days of peptide administration. The comparison revealed that the experimental groups diminished their food intake between $-12.4 \pm 52.3$ and $-48.0 \pm 38.6$ kilocalories. The reduction in food intake was statistically significant for each of the groups, except P83 (Table 3). The fat control group presented decreased food intake but it was not significant (Table 3).

The analysis to establish differences among groups proved that experimental groups $\mathrm{P} 78$ to $\mathrm{P} 81$ and P82 and P84 consumed similar amounts of food amongst them and lower amounts than the fat control group. The $\mathrm{P} 83$ group was only statistically different from P84 (ANOVA: $p=0.038$ ) (Table 3).

Analysis of food consumption data during the treatment days shows periods of greater and lower food consumption and not a continuous decrease, as noted with body weight. Table 4 shows that groups SR 116 and SH 95 tended to consume the same amount of calories during the five days. For the P81 and P82 groups, food intake diminished significantly during days 3 and 4, while for the P84 group there was a drastic reduction $(10 \mathrm{kcal} /$ day $)$ during the first two days followed by a four-fold increase $(40 \mathrm{kcal} / \mathrm{day})$ to diminish to $20 \mathrm{kcal}$ on the last day. For the P83 group, there were no significant daily differences in consumption (Table 4).

Intra-group comparison according to the dosage of administration of each peptide did not confirm significant differences (Anova $\mathrm{p}>0.05$ ).

Blood lipid concentrations. Results of blood lipid determination after the last peptide administration are shown in Table 5.

Data show differences among peptide groups and controls in concentrations of TChol HDLc, LDLc, and TG. These differences evidence that in all the experimental groups there was an increase in TChol and LDLc with respect to the normal control (ANOVA in Table 5). This effect could be due to the high-fat diet, given that the fat control also presented significantly greater concentrations than the normal control. HDLc is similar in all the groups and TGs in P80 and P81 show higher concentrations than that of the control and experimental groups (ANOVA in Table 5). 
Table 2

Average weight of the control groups and the experimental groups during the period of peptide administration. Value of the slope of each curve

\begin{tabular}{|c|c|c|c|c|c|c|c|}
\hline \multirow[t]{3}{*}{ Group } & \multirow{2}{*}{$\begin{array}{l}\text { Initial weight } \\
\text { (g) }\end{array}$} & \multicolumn{4}{|c|}{ Weight on day } & \multirow{2}{*}{$\begin{array}{c}\text { Final } \\
\text { weight (g) }\end{array}$} & \multirow{2}{*}{$\begin{array}{l}\text { Curve } \\
\text { slope }\end{array}$} \\
\hline & & $2(g)$ & $3(\mathrm{~g})$ & $4(g)$ & $5(g)$ & & \\
\hline & $X$ DS & DS & DS & DS & DS & DS & DS \\
\hline \multicolumn{8}{|l|}{ Normal } \\
\hline control & $261.9 \pm 14.8$ & $262.0 \pm 15.3$ & $262.7 \pm 17.0$ & $261.8 \pm 15.6$ & $262.8 \pm 15.7$ & $263.9 \pm 17.5$ & $0.3229 \pm 0.6$ \\
\hline \multicolumn{8}{|l|}{ Fat } \\
\hline control & $291.6 \pm 19.7$ & $289.4 \pm 21.3$ & $289.9 \pm 20.0$ & $290.4 \pm 19.9$ & $288.5 \pm 19.0$ & $288.5 \pm 19.9$ & $-0.5024 \pm 1.4$ \\
\hline SR116 & $293.6 \pm 23.3$ & $290.6 \pm 24.0$ & $290.0 \pm 23.6$ & $289.0 \pm 23.6$ & $286.7 \pm 23.6$ & $286.5 \pm 23.4$ & $-1.3816 \pm 0.8$ \\
\hline SH95 & $294.6 \pm 24.0$ & $291.7 \pm 24.6$ & $290.6 \pm 24.7$ & $288.3 \pm 24.3$ & $286.6 \pm 24.0$ & $287.9 \pm 23.9$ & $-1.4439 \pm 0.8$ \\
\hline P80 & $308.9 \pm 42.3$ & $307.0 \pm 43.6$ & $303.9 \pm 42.0$ & $304.0 \pm 41.3$ & $303.7 \pm 40.5$ & $302.5 \pm 39.9$ & $-1.2389 \pm 1.3$ \\
\hline P81 & $306.4 \pm 30.8$ & $304.1 \pm 31.0$ & $301.8 \pm 30.4$ & $301.4 \pm 29.9$ & $300.8 \pm 30.5$ & $299.9 \pm 30.0$ & $-1.2204 \pm 1.3$ \\
\hline P82 & $281.2 \pm 30.3$ & $280.6 \pm 31.0$ & $279.7 \pm 30.4$ & $279.8 \pm 29.6$ & $279.2 \pm 29.5$ & $278.0 \pm 30.0$ & $-0.5656 \pm 1.1$ \\
\hline P83 & $279.6 \pm 13.0$ & $277.9 \pm 13.5$ & $278.4 \pm 13.4$ & $279.3 \pm 13.2$ & $279.6 \pm 12.3$ & $276.7 \pm 13.0$ & $-0.2448 \pm 0.7$ \\
\hline P84 & $286.9 \pm 25.0$ & $286.9 \pm 24.9$ & $286.7 \pm 24.6$ & $285.7 \pm 24.1$ & $285.7 \pm 24.7$ & $286.3 \pm 25.7$ & $-0.216 \pm 0.9$ \\
\hline
\end{tabular}

Table 3

Mean food intake in kilocalories according to days of peptide treatment

\begin{tabular}{|c|c|c|c|c|c|c|c|c|}
\hline \multirow[t]{3}{*}{ Group } & \multirow[t]{3}{*}{$\mathbf{N}$} & \multicolumn{4}{|c|}{$\begin{array}{l}\text { Mean food intake in kcal } \\
\text { during the } 5 \text { days }\end{array}$} & \multirow{2}{*}{\multicolumn{2}{|c|}{$\begin{array}{l}\text { Difference of kcal } \\
\text { intake }\end{array}$}} & \multirow[t]{3}{*}{$\begin{array}{l}\mathbf{p} \text { value } T \text { test between } \\
\text { related samples }^{1}\end{array}$} \\
\hline & & \multicolumn{2}{|c|}{$\begin{array}{l}\text { prior to peptide } \\
\text { administration }\end{array}$} & \multicolumn{2}{|c|}{$\begin{array}{c}\text { of peptide } \\
\text { administration }\end{array}$} & & & \\
\hline & & $x$ & DS & $x$ & DS & $\mathbf{x}$ & DS & \\
\hline SR 116 & 24 & \multicolumn{2}{|c|}{$169.0 \pm 33.1$} & \multicolumn{2}{|c|}{$145.8 \pm 33.1$} & \multicolumn{2}{|c|}{$-23.1 \pm 37.3$} & $p<0.006^{2}$ \\
\hline SH 95 & 24 & \multicolumn{2}{|c|}{$166.4 \pm 35.1$} & \multicolumn{2}{|c|}{$142.4 \pm 29.4$} & \multicolumn{2}{|c|}{$-24.0 \pm 37.3$} & $p<0.006$ \\
\hline P80 & 22 & \multicolumn{2}{|c|}{$196.2 \pm 34.1$} & \multicolumn{2}{|c|}{$153.7 \pm 31.1$} & \multicolumn{2}{|c|}{$-42.5 \pm-43.8$} & $p<0.00009$ \\
\hline P81 & 22 & \multicolumn{2}{|c|}{$197.3 \pm 30.5$} & \multicolumn{2}{|c|}{$152.5 \pm 41.6$} & \multicolumn{2}{|c|}{$-44.8 \pm 47.4$} & $p<0.00009$ \\
\hline P82 & 16 & \multicolumn{2}{|c|}{$218.1 \pm 27.4$} & \multicolumn{2}{|c|}{$173.8 \pm 31.2$} & \multicolumn{2}{|c|}{$-44.4 \pm 28.9$} & $p<0.00009$ \\
\hline P83 & 15 & \multicolumn{2}{|c|}{$217.4 \pm 24.3$} & \multicolumn{2}{|c|}{$205.0 \pm 42.0$} & \multicolumn{2}{|c|}{$-12.4 \pm 52.3$} & $p=0.3$ \\
\hline P84 & 19 & \multicolumn{2}{|c|}{$167.9 \pm 23.1$} & \multicolumn{2}{|c|}{$119.9 \pm 29.6$} & \multicolumn{2}{|c|}{$-48.0 \pm 38.6$} & $p<0.00009$ \\
\hline Fat control & 7 & \multicolumn{2}{|c|}{$169.0 \pm 22.9$} & \multicolumn{2}{|c|}{$159.0 \pm 31.5$} & \multicolumn{2}{|c|}{$-10.0 \pm 38.9$} & $p=0.3$ \\
\hline
\end{tabular}

1. $p=0.012$. Nonparametric test two samples

It can also be observed that a) treatment with $\mathrm{SH} 95$ and P80 seems to diminish the effect of the diet on TChol and LDLc; although, without significant differences. b) Treatment with P82 and P84 increases the effect of the diet on TChol and LDLc, but without statistical significance (Table 5).

Concentrations of glycerol liberated in the medium and DNA fragmentation. Table 5 shows concentrations of glycerol liberated on the medium in the control and experimental groups. The groups in which the greatest concentration of glycerol was liberated were the SH 95 and SR 116 groups. The glycerol concentration for the SH95 group was similar to the amount of glycerol liberated by the SR 116 group 
Table 4

Mean food intake in kilocalories according to days of peptide treatment

\begin{tabular}{lccc}
\hline Group & \multicolumn{3}{c}{ Calories } \\
\cline { 2 - 4 } & $\begin{array}{c}\text { 2 days } \\
\text { (day 1-3) }\end{array}$ & $\begin{array}{c}\text { 2 days } \\
\text { (day 4-5) }\end{array}$ & $\begin{array}{c}\text { 1 day } \\
\text { (day 5-6 post- } \\
\text { treatment) } \\
\end{array}$ \\
& X DS & X DS & X DS \\
\hline Fat control & $40.7 \pm 29.7$ & $83.6 \pm 25.3$ & $34.7 \pm 18.0$ \\
SR 116 & $62.4 \pm 16.2$ & $50.5 \pm 18.3$ & $32.9 \pm 12.4$ \\
SH 95 & $55.9 \pm 18.7$ & $52.5 \pm 25.5$ & $34.0 \pm 12.9$ \\
P80 & $81.5 \pm 25.3$ & $21.6 \pm 12.3$ & $50.5 \pm 18.8$ \\
P81 & $72.4 \pm 31.5$ & $25.3 \pm 18.9$ & $54.8 \pm 27.7$ \\
P82 & $56.5 \pm 31.9$ & $72.8 \pm 14.6$ & $44.5 \pm 16.6$ \\
P83 & $71.2 \pm 30.7$ & $84.7 \pm 16.0$ & $40.1 \pm 15.4$ \\
P84 & $19.3 \pm 14.5$ & $80.2 \pm 32.3$ & $20.4 \pm 9.4$ \\
\hline
\end{tabular}

and apparently greater than that of the control groups and the other experimental groups (ANOVA $\mathrm{p}=0.001$ ). No significant differences were found when comparing the amount of glycerol liberated according to the dosage administered of each of the peptides (ANOVA $p>0.05$ ).

DNA fragmentation was noted in groups P80, P81, SH 95, SR 116, and P82; the effect was partial in all the groups because it was present in some of the animals that made up each experimental group (Table 6). The divergence in the number of cases with fragmentation hindered the possibility of confirming if the fragmentation percentages perceived in the groups were statistically different from the control group. In spite of this, a tendency for greater effect was noted with P80 and SH 95 peptides. The mean percentage of fragmentation was $2.8 \% \pm 1.3$, the minimum value was $1.4 \%$ and the maximum value was $6.6 \%$.

\section{DISCUSSION}

Evaluation of body weight during the period of peptide administration revealed that all the experimental animals except for those in P84, experienced some weight reduction caused by the peptides administered. These results coincide with previous studies ${ }^{6-8}$ and evidence, at the same time, the potential of the peptides in treating obesity due to consumption of high-fat diets. The results observed in this study also support the hypothesis proposed by other authors in that peptides similar to leptin can have a potential application in human or veterinary medicine to control adiposity and the metabolic sequelae associated with obesity ${ }^{21}$.

The results show that, in spite of the fact that all the

Table 5

Mean concentration of blood lipids according to groups conformed as controls and experimental groups. Mean concentrations of glycerol freedom in the medium cell

\begin{tabular}{|c|c|c|c|c|c|c|c|c|c|c|c|c|}
\hline \multirow{3}{*}{ Group } & \multirow{3}{*}{$\mathbf{N}$} & \multicolumn{8}{|c|}{ Mean (mg/dl) } & \multirow{2}{*}{\multicolumn{3}{|c|}{ Glycerol }} \\
\hline & & \multicolumn{2}{|c|}{ CT } & \multicolumn{2}{|c|}{ HDLC } & \multicolumn{2}{|c|}{ LDLc } & \multicolumn{2}{|c|}{ TG } & & & \\
\hline & & $x$ & DS & $x$ & DS & $x$ & DS & $x$ & DS & $\mathbf{N}$ & $x$ & DS \\
\hline SR 116 & 21 & \multicolumn{2}{|c|}{$95.9 \pm 29.4$} & \multicolumn{2}{|c|}{$43.8 \pm 11.9$} & \multicolumn{2}{|c|}{$35.9 \pm 30.4$} & \multicolumn{2}{|c|}{$81.0 \pm 34.9$} & 22 & \multicolumn{2}{|c|}{$9.4 \pm 10.3^{*}$} \\
\hline SH 95 & 22 & \multicolumn{2}{|c|}{$88.7 \pm 23.2$} & \multicolumn{2}{|c|}{$43.7 \pm 11.4$} & \multicolumn{2}{|c|}{$27.4 \pm 19.4$} & \multicolumn{2}{|c|}{$88.0 \pm 48.3$} & 23 & \multicolumn{2}{|c|}{$12.6 \pm 12.2^{*}$} \\
\hline P80 & 24 & \multicolumn{2}{|c|}{$85.4 \pm 16.1$} & \multicolumn{2}{|c|}{$37.3 \pm 14.9$} & \multicolumn{2}{|c|}{$23.3 \pm 17.8$} & \multicolumn{2}{|c|}{$124.1 \pm 43.8$} & 24 & \multicolumn{2}{|c|}{$5.8 \pm 6.5$} \\
\hline P81 & 23 & \multicolumn{2}{|c|}{$98.2 \pm 37.4$} & \multicolumn{2}{|c|}{$37.9 \pm 15.0$} & \multicolumn{2}{|c|}{$38.6 \pm 37.3$} & \multicolumn{2}{|c|}{$129.3 \pm 53.4$} & 23 & \multicolumn{2}{|c|}{$4.7 \pm 2.4$} \\
\hline P82 & 16 & \multicolumn{2}{|c|}{$116.7 \pm 41.0$} & \multicolumn{2}{|c|}{$50.7 \pm 13.2$} & \multicolumn{2}{|c|}{$48.1 \pm 37.6$} & \multicolumn{2}{|c|}{$89.9 \pm 32.7$} & 15 & \multicolumn{2}{|c|}{$6.1 \pm 1.4$} \\
\hline P83 & 15 & \multicolumn{2}{|c|}{$92.0 \pm 25.7$} & & $7 \pm 12.0$ & 22. & $0 \pm 22.3$ & $75 . \varsigma$ & $9 \pm 25.9$ & 15 & & $.2 \pm 1.2$ \\
\hline P84 & 19 & 110.8 & \pm 38.0 & & $4 \pm 17.2$ & 52. & $3 \pm 29.5$ & $71 . \varepsilon$ & $3 \pm 20.1$ & 19 & & $.1 \pm 1.0$ \\
\hline Normal control & 6 & $77.0 \pm$ & \pm 15.9 & & $9 \pm 22.3$ & & $.7 \pm 8.6$ & 92. & $3 \pm 6.7$ & 5 & & $.2 \pm 2.2$ \\
\hline Control graso & 7 & 104.9 & \pm 49.2 & 47 & $5 \pm 16.0$ & 40 & $0 \pm 41.2$ & $87 . \subseteq$ & $9 \pm 32.7$ & 7 & & $.1 \pm 1.9$ \\
\hline ANOVA* & & $p=0$ & 0.02 & & $=0.005$ & & $=0.012$ & $p<0$ & .00009 & & & \\
\hline
\end{tabular}

* Indicates if differences do exist 
Table 6

Treatment groups in which DNA fragmentation was observed in adipose tissue

\begin{tabular}{|c|c|c|c|c|c|c|c|}
\hline \multirow[t]{3}{*}{$\begin{array}{l}\text { Group according } \\
\text { to peptide }\end{array}$} & \multirow[t]{3}{*}{$\begin{array}{l}\text { Number of cases } \\
\text { with fragmentation }\end{array}$} & \multirow[t]{3}{*}{$\begin{array}{l}\text { Group according } \\
\text { to peptide }\end{array}$} & \multirow[t]{3}{*}{$\begin{array}{l}\text { Number of cases } \\
\text { with fragmentation }\end{array}$} & \multicolumn{4}{|c|}{$\begin{array}{l}\% \text { of fragmentation } \\
\text { according to }\end{array}$} \\
\hline & & & & & peptide & conc & centration \\
\hline & & & & $\%$ & Mean DS & $\%$ & Mean DS \\
\hline \multirow[t]{2}{*}{ SR 116} & 1 & SR $116-5.0$ & 1 & 3 & - & 3 & - \\
\hline & & SH 95-2.5 & 1 & - & $2.9 \pm 2.5$ & 6.6 & - \\
\hline \multirow[t]{3}{*}{ SH 95} & 4 & SH 95-5.0 & 2 & & & - & $1.4 \pm 0.2$ \\
\hline & & SH 95-20.0 & 1 & & & 2.1 & - \\
\hline & & P 80-2.5 & 5 & - & $2.9 \pm 1.1$ & - & $2.4 \pm 0.8$ \\
\hline \multirow[t]{3}{*}{ P80 } & 19 & P 80-5.0 & 5 & & & - & $3.3 \pm 1.3$ \\
\hline & & P 80-10.0 & 5 & & & - & $3.5 \pm 0.9$ \\
\hline & & P 80-20.0 & 4 & & & - & $1.8 \pm 0.4$ \\
\hline P81 & 5 & P 81-5.0 & 5 & - & $2.0 \pm 0.5$ & - & $2.0 \pm 0.5$ \\
\hline P82 & 1 & P 82-10.0 & 1 & 4.4 & - & 4.4 & - \\
\hline
\end{tabular}

peptides were designed in such a way that they were variations of an amino acid of the active sequence with a minimum coupling energy to the receptor, not all peptides respond in the same manner, as was expected. Indeed, the SR 116 peptide had already been shown to have a similar effect as leptin in mice ${ }^{6,7}$ and in the current work it shows a similar effect in rats with increased adiposity due to fat diet. We designed the $\mathrm{SH}$ 95 from the sequence of human leptin ${ }^{15}$ and found that it also has a similar effect as SR116 in rats. Peptides P80 and P81 are variations of SH95 in amino acid 103 (D/ $\mathrm{G})$ and $95(\mathrm{G} / \mathrm{S})^{15,16}$, respectively, and behave similarly. Note that the change of aspartic for glutamic does not significantly alter the conformation or the minimum energy of the P80. The lack of effect of the change of serine for glutamic in position 95 of P81 is more difficult to explain, especially when changes in the same amino acid of the P82 to P84 peptides ${ }^{16}$ almost completely diminish the effect.

Weight reduction in animals that were administered peptides SR116, SH 95, P80, and P81 could be explained by a possible interaction of the peptides with the hypothalamic receptor of leptin, which would suppress appetite. In effect, we found that administering these peptides diminished the caloric intake of the animals during the five days of the experiment. It is possible, then, that processes associated to energy metabolism are stimulated via the activation of anorexigenic signals and the inhibition of paths associated to increased appetite $^{11,22,23}$.

In addition to appetite reduction, it is possible that the interaction with the receptor also involves other signals that increase lipolysis and diminish adiposity; thus, contributing to diminished body weight ${ }^{4,6,22}$. In this study, it is interesting to observe that in the adipose tissue of animals administered these four peptides there was significant increase in the production of glycerol when incubated in preparations free of cells for 90 minutes at $37^{\circ} \mathrm{C}$; this increase was apparently high in $\mathrm{PH}$ 95. These results suggest that in animals treated with these peptides an action was produced on the lipid metabolism, probably a lipolysis increase in the adipocyte that could happen similarly to that reported with leptin, acting through an autocrine/paracrine action or through actions controlled by the central nervous system to stimulate the metabolic routes that generate faster use of triglyceride deposits and inhibit their synthesis ${ }^{4,5,24}$.

Likewise, although we found no DNA fragmentation in the adipocytes ofall the animals that were administered the peptides, it is clear that all the animals receiving P80, independent of the dosage administered, showed DNA fragmentation. For the SR 116, only adipocytes from one animal and in the SH 95 from four animals showed DNA fragmentation. Note that for P83 and P84 there was no fragmentation, which would indicate that 
in these animals there was no decrease of adiposity that would contribute to no weight loss. It is possible that this is one of the factors that explain why administering P84 diminishes food intake without weight reduction. These results suggest the possibility of stimulating apoptosis processes similar to that observed with administration of recombinant leptin ${ }^{13,20,21}$, through hypothalamic signals associated with the reduction in NPY levels ${ }^{14}$, to increased PPAR $\gamma$ expression and decreased levels of the tumor necrosis factor-alpha, the latter as a secondary effect to reduced fat mass ${ }^{13}$. Similar to the angiopoietin 2 (Ang-2) expression, the angiogenesis antagonist, promotes apoptosis to increase the production of the pro-apoptotic BAX proteins and to increase oxidation of fatty acids in endothelial cells via activation of the Kinase A protein ${ }^{13,20}$.

Some studies have shown that one of the leptin mechanisms to reduce fat deposits is through its ability to diminish synthesis and secretion of insulin from the pancreatic $b$ cells and the sensitivity of insulin in adipose tissue ${ }^{22}$. We did not find this effect in our experiments ${ }^{17}$, which makes it unlikely that the weight loss found through the administration of SR 116, SH95, and $\mathrm{P} 80$ and $\mathrm{P} 82$ involves this mechanism.

As with the study by Grasso et al. ${ }^{6-8}$ the effect of weight loss was greater during the first days of peptide administration and not as the experiment progressed.

Several studies reveal that a high intake of fats, particularly saturated fats, increases the plasma values of TChol, LDLc, and TG and decreases those of HDLc ${ }^{25}$. Increases in these parameters observed in all the animals may be due to the diet consumed. However, administration of recombinant leptin in mice has demonstrated its potential in diminishing TChol, LDLc, and TG concentrations and increasing HDL concentrations ${ }^{15}$. Note that administering $\mathrm{SH} 95$ and P80 seems to partially palliate the increase caused by the diet (Average TChol $90 \mathrm{mg} / \mathrm{dl} \mathrm{Vs.} 106 \mathrm{mg} / \mathrm{dl}$ in the rest of the groups) as done by the recombinant leptin; the same was found with LDLc. Nevertheless, administering P80 and P81 increases TGs, contrary to that found with recombinant leptin. It is possible that these differences are due to how peptides interact with both hypothalamic receptors and the very adipocytes.

Peptides SR 116 and SH 95 carried out the same biological actions. This finding suggests that the SH 95 peptide of the human leptin sequence executes the same biological functions related to the energetic metabolism and regulation of body fat in the SR 116 segment.

Comparison of the variables according to the concentrations under which each peptide was administered (intra-groups) did not show statistically significant differences. The results, hence, indicate that there was no important variation in the effects observed with the peptides according to the dosage administered, suggesting a maximum effect in a dosage of $2.5 \mathrm{mg} / \mathrm{kg}$.

In conclusion, the findings suggest that the 95-109 human sequence of the human leptin molecule identified in the Protein Data Bank as PDB is the human segment similar to the mouse 116-130 leptin with probable biological activity to regulate body weight and appetite and generate lipolysis, as well as possibly apoptosis in the adipocyte. Likewise, it is insinuated that intraperitoneal administering of synthetic peptides in Wistar rats may execute related actions to body fat control in an animal model of obesity associated to excessive intake of fat; specifically, generate diminished appetite, reduced body weight, increased lipolysis, and possible apoptosis to reduce fat deposits.

The results also indicate differences in the action executed by each of the peptides and in the magnitude of the effect, highlighting the possibility of controlling the biological response when modifying the structure of these molecules. Other research is required to corroborate the effect of the peptides that generated greater biological response, compare the results with respect to other treatment alternatives, evaluate their action over a longer period of time, and identify the mechanisms through which they execute the action on the organism.

Conflict of interest. The authors manifest having no conflicts of interest in the elaboration and execution of this project.

\section{ACKNOWLEDGMENTS}

The authors thank Dr. Carlos Corredor Pereira for his suggestions and contributions to this publication and also thank the professionals who participated in collecting the blood samples and in animal control.

\section{REFERENCES}

1. Ceddia RB. Direct metabolic regulation in skeletal muscle and 
fat tissue by leptin: implications for glucose and fatty acids homeostasis. Int J Obes (Lond). 2005; 29: 1175-83.

2. Wang M, Lee Y, Unger R. Novel form of lipolysis induced by leptin. J Biol Chem. 1999; 25: 17541-4.

3. Zhang H, Kumar S, Bernett A, Eggo M. Intrinsic site-specific differences in the expression of leptin in human adipocytes and its autocrine effects on glucose uptake. JClin Endocrinol. 1999; 7: 2550-5.

4. Rodríguez VM, Macarulla, MT Echevarría, E, Portillo MP. Lipolysis induced by leptin in rat adipose tissue from different anatomical locations. Eur J Nutr. 2003; 42: 149-53.

5. Grasso P, Leinung MC, Ingher SP, Lee DW. In vivo effects of leptin related synthetic peptides on body weight and food intake in female ob/ob mice. Localization of leptin activity to domains between amino acid residues 106-140. Endocrinology. 1997; 4: 1413-18.

6. Rozhavskaya A, Lee D, Leinung M, Grasso P. Design of a synthetic leptin agonist. Effects on energy balance, glucose homeostasis, and thermoregulation. Endocrinology. 2000; 7 : 2501-7.

7. Grasso P, Rozhavskaya-Arena M, Leinung MC, Lee DW. DLeu-4-OB3, a synthetic leptin agonist, improves hyperglycemic control in C57BL/6jJ ob/ob mice. Regul Pept. 2001; 101: 1239 .

8. Scarpace PJ, Zhang Y. Leptin resistance: a pre-disposing factor for diet-induced obesity. Am J Physiol Regul Integr Comp Physiol. 2009; 3: 493-500.

9. Enriori PJ, Evans AE, Sinnayah P, Cowley MA. Leptin resistance and obesity. Obesity. 2006; 14 (Suppl 5): 254-8.

10. Plantenga M, Saris W, Hukshorn C, Campfield ?. Effects of weekly administration of pegylated recombinant human $\mathrm{OB}$ protein on appetite profile and energy metabolism. Am J Clin Nutrition. 2001; 74: 426-34.

11. Kamohara S, Burcelin R, Halaas J, Friedman J, Charron M. Acute stimulation of glucose metabolism in mice by leptin treatment. Nature. 1997; 6649: 374-7.

12. Burcelin R, Kamohara S, Li J, Tannenbaum G, Charron M, Friedman J. Acute intravenous leptin infusion increases glucose turnover but not skeletal muscle glucose uptake in ob/ob mice. Diabetes. 1999; 48: 1264-9.

13. Gullicksen PS, Asuman DB, Dean RG, Hartzell DL, Baile CA.
Adipose tissue cellularity and apoptosis after intracerebroventricular injections of leptin and 21 days of recovery in rats. Int J Obesity. 2003; 27: 302-12.

14. Kalaivanisailaja J, Manju V, Nalini N. Lipid profile in mice fed a high-fat diet after exogenous leptin administration. Pol J Pharmacol. 2003; 5: 763-9.

15. Poveda E, Lareo L. Diseño teórico de péptidos miméticos de leptina como farmacóforo para tratamiento de obesidad. Lect Nutr. 2001; 8: 40-52.

16. Poveda E, Trujillo P, Ruiz F, López E. Glicemia y concentraciones de insulina en sangre de ratas Wistar sometidas a dieta alta en grasa y a tratamiento con péptidos miméticos de leptina. Biomedica. 2008; 28: 50-63.

17. Qian H, Azain MJ, Hartzell DL, Baile CA. Increased leptin resistance as rats grow to maturity. Proc Soc Exp Biol Med. 1998; 2: 160-5.

18. Wang T, Hartzell DL, Rose BS, Flatt WP, Hulsey MG, Menon $\mathrm{NK}$, et al. Metabolic responses to intracerebroventricular leptin and restricted feeding. Physiol Behav. 1999; 4-5: 83948.

19. Rodbell M. Metabolism of isolated fat cells. Effects of hormones on glucose metabolism and lipolysis. J Biol Chem. 1964; 2: 375-80.

20. Della-Fera MA, Choi YH, Hartzell DL, Duan J, Hamrick M, Baile CA. Sensitivity of ob/ob mice to leptin-induced adipose tissue apoptosis. Obes Res. 2005; 9: 1540-7.

21. Maedler K, Schulthess FT, Bielman C, Berney T, Bonny C, Prentki $\mathrm{M}$, et al. Glucose and leptin induce apoptosis in human beta-cells and impair glucose-stimulated insulin secretion through activation of c-Jun $\mathrm{N}$-terminal kinases. FASEB J. 2008; 22: 1905-13.

22. Ramsay TG. Porcine leptin inhibits lipogenesis in porcine adipocytes. J Anim Sci. 2003; 81: 3008-17.

23. Sahu A. Leptin signalling in the hypothalamus: emphasis on energy homeostasis and leptin resistance. Front Neuroendocrinol. 2003; 24: 225-53.

24. Shen J, Tanida M, Mtijima A, Nagaik. In vivo effects of leptin on autonomic nerve activity and lipolysis in rats. Neurosci Lett. 2007; 416: 193-7.

25. Denke MA. Dietary fats, fatty acids, and their effects on lipoproteins. Curr Atheroscler Rep. 2006; 6: 466-71. 